\title{
ASSESSMENT OF VULNERABILITY OF FARMING HOUSEHOLDS TO CLIMATE CHANGE IN EKITI STATE, NIGERIA
}

\author{
MUHAMMAD-LAWAL, ${ }^{1}$ A., ${ }^{*}$ SALAU, S.A. ${ }^{2}$ and SAKA, A.Y. 1 \\ DOI: $\underline{\text { http://dx.doi.org/10.4314/ejesm.v5i2.8 }}$
}

Received 13 ${ }^{\text {th }}$ February 2012; accepted 31 ${ }^{\text {st }}$ March 2012

\begin{abstract}
Production systems and livelihoods in South Western Nigeria are at risk of climate variability and change. The study examined the vulnerability of farming households in Ekiti State of Nigeria to climate change. A total of 120 respondents were randomly selected, interviewed and used for data analysis. Results of the study indicated that the farming households in Ekiti State witnessed change in weather conditions as reflected in unusual downpour of rain thus affecting their productivity. Most of these household heads were young, males, literate, and experienced but relied mainly on personal savings and money borrowed from friends and relatives for farming. The results also indicated that climate change resulted in low productivity, low income, as well as poor standard of living of the respondents. The most widely adopted coping strategy by the respondents was to switch to other sources of income whenever there was unpredictable variation in climate condition. This study therefore calls for the need for government policy to encourage farming households in Ekiti State to obtain loan from banks and micro-credit institutions by reducing interest rate on loans for crop production as well as removing the stringent conditions attached to loans.
\end{abstract}

Keywords: Climate change, vulnerability, farming households

\section{Introduction}

The world's climate has always been changing between hotter and cooler periods due to various factors. These changes which constitute major challenges to humanity have been occurring for at least a century (Erda et. al. 2007; Pender, 2008). However recent evidence and predictions indicate that climate changes are accelerating and will lead to wide-ranging shifts in climate variable. Specifically, in 2007 the Fourth Assessment of Report of the Intergovernmental Panel on Climate Change (IPCC) effectively put to rest many of the debates surrounding the science of climate change, rending evidence solid enough to impaction. If found that the warning of the climate system was "unequivocal and that a number of attendant effects were already observable (Pender 2008).

The global current average temperature is projected to increase by a record high, of $1.4-5.8^{\circ} \mathrm{c}$ in the next century compared to temperature level in 1990 (Sygna, 2005). Consequently, climate change is attracting ever more attention from the media, academic, politicians and even business, as evidence mounts about its scale and seriousness, and the speed at which it is affecting the world. In the past two decades, several studies have been

\footnotetext{
1Department of Agricultural Economics and Farm Management Faculty of Agriculture, University of Ilorin, Nigeria

${ }^{2}$ Department of Agricultural Economics and Extension Services,

College of Agriculture and Veterinary Medicine, Kwara State

University, Malete, Nigeria.

*Corresponding author email: talk2salaushehu@yahoo.com
}

conducted aimed at analyzing the possible effects of climate change on a range of natural and social systems, and at identifying and evaluating options to respond to these effect (Klein, 2004). As a result, much has been reported on the ways in which unchecked climate change might negatively impact prospects of countries for sustainable development (UNCTD, 2009). The impact of climate change is however spatially heterogeneous across a diverse range of geopolitical scales. For instance at the international level, the risk is generally believed to be more acute in developing countries because they rely heavily on climate sensitive sectors, such as agriculture and fisheries, and have a low GDP, high levels of poverty, low levels of education and limited human institutional, economic, technical and financial capacity (IPCC, 2007; WBGU, 2008). At the national level, various ecosystem sectors, and sub- populations within a country have been identified as being more or less at-risk in a changing climate depending on length of coastline, level of emergency preparedness and economic and livelihood sensitivity to climate (IPCC, 2007). 
Change in climate will interact with other form of stress associated with agricultural production and affect crop yields and productivity in different ways, depending on the type of agricultural practices and system in place (Watson et al., 2005). The main direct effects will be through changes in temperature, precipitations, length of growing season and timing of extreme of critical threshold events relative to crop development. The implications are that vulnerability (which was defined by Blaikie (2006) as the characteristics of a person or a group to anticipate, cope, resist and recover from the impacts of natural hazard) of countries and societies to the effects of climate change depends not only on the magnitude of climate stress but also on the sensitivity and capacity of affected societies to adopt to or cope with such stress (NEST 2004). Thus, the need assess the impacts of climate change, identify the various coping strategies used by households and estimate the financial implications of the effects of climate change on farming households becomes imperative.

\section{Conceptual Framework}

Concept of vulnerability: Vulnerability is the degree to which a system is susceptible to or unable to cope with adverse effects of climate change, including climate variability and extremes. It is a function of character, magnitude and rate of climate variation to which a system is exposed, its sensitivity and its adaptive capacity IPCC (2001).

According to Okunmadewa (2003), Vulnerability is the likelihood of a shock causing a significant welfare loss. He was of the opinion that vulnerability depends on exposure to risks (uncertain events that can lead to welfare losses) and on risk management actions taken to respond to risks, which may be ex-ante (before) or ex-post (after). Santiago (2001) stated that vulnerability is the extent to which a natural or social system is susceptible to sustaining damage from climate change.

To be vulnerable according to The World Bank (2004), can therefore be understood as the propensity of a society (households) to experience substantial damage and disruption on results of hazards (e.g. drought, flood, conflicts etc.). Vulnerability is not simply a function of exposure, but also of people's capacity to adapt to change. If the people's capacity to adapt to change remains unchanged, increased exposure will lead to increased vulnerability. Vulnerability is caused by inequality, inappropriate governance structures and maladaptive economic and agricultural development (Jagtap, 1995). The vulnerability of farming households in Nigeria can be view in terms of the problems encountered by households that hamper increased production. This can be categorized into shocks and trends. Shocks include: drought, pest and diseases and flood while trends are fluctuation in prices, inconsistencies in policies, inadequate access to credit, marketing problems and inadequate manpower during season.

Concept of adaptation: Adaptation are adjustment to or interventions, which take place in order to manage the losses or take advantage of the opportunities presented by a changing climate (IPCC, 2001). Adaptation is the process of improving time scales, from short term (e.g., seasonal to annual) to long term (e.g., decades to centuries). The IPCC (2001) defines adaptive capacity as the ability of a system to adjust to climate change (including climate variability and extremes), to moderate potential damages, to take advantage of opportunities, or to cope with consequences. The goal of adaptation measure should be to increase the capacity of a system to survive external shocks or changes.

According to Santiago (2001), Adaptation involves adjustment to enhance the viability of social and economic activities and to reduce their vulnerability to climate, including its current variability and extreme events as well as longerterm climate change. Adaptation to climate is the process through which people reduce the adverse effects of climate on their health and wellbeing and take advantage of opportunities that their climatic environment provides. The term adaptation means any adjustment, whether passive, reactive or anticipatory that is proposed as a means for ameliorating the anticipated adverse consequences associated with climate change (Alao, 1999).

According to IPCC Third Assessment Report, adaptation has the potential to reduce adverse impacts of climate change and to enhance beneficial impacts but will incur cost and will not prevent all damages. Adaptations are adjustments or interventions; which takes place in order to manage the losses or take advantage of the opportunities presented by a changing climate (IPCC, 2001). Adaptation is the process of 
improving society's ability to cope with changes in climatic conditions across time scales, from short term to (seasonal to annual) to long term (e.g. decades to centuries). The IPCC (2001) defines adaptive capacity as the ability of a system to adjust to climate change (including climate variability and extremes), to moderate potential damages, to take advantage of opportunities, or to cope with the consequences. The goal of adaptation measure should be to increase the capacity of a system to survive external shocks or change.

The assessment of coping strategies (adaptation options) adopted by farmers to sustain adverse effect imposed on production by climate change is important to formulate policies that enhance adaptation as a tool for managing a variety risks associated with climate change and it also provide information that increases the capacity of farmers to survive external shocks or changes.

Important adaptation options in the agricultural sector include, Crop diversification, mixed cropping, livestock farming system, using different crop varieties, changing planting and harvesting dates, mixing less productive, drought resistant varieties and high yield water sensitive crops (Jagtap, 1995). Agriculture adaptation involves 2 types of modifications in production systems. The first is increased diversification that involves engaging in production activities that are drought tolerant and or resistant to temperature stresses as well as activities that make efficient use and take full advantage of prevailing water and temperature conditions, among other factors. Crop diversification can serve as insurance against rainfall variability as different crops are affected differently by climate events. The second strategy focuses on crop management practices geared towards ensuring that critical crop growth stages do not coincide with very harsh climatic condition such as mid-season droughts.

Farming households adapt to dry spell and lengthening growing season resulting from unexpected climate change by constructing irrigation system in order to improve their productivity. The adaptive decision make by these households in response to seasonal variation in climate factors are influenced by a number of socio-economic factors that include farm household characteristics, household resource, access to information and availability to formal institutions (input and output markets) for even distribution and consumption. Adaptation to climate change however involves changes in agricultural management practices in response to changes in climate conditions. It often involves a combination of various individual responses at the farm-level and assumes that farmers have access to alternative practices and technologies available in the region.

\section{Methodology \\ Study Area}

This research work was conducted in Ekiti State, Nigeria. Ekiti State is one of the six states constituting the South-Western region of Nigeria. Although some parts of the region are fairly urbanized, the greater majority of the population still lives in the rural areas. The State shares boundary in the North-West with Kwara State, in the North-East with Kogi State and in the South by Ondo State. Ekiti State is located on latitude $7^{0} 25^{1}$ and $8^{0} 5^{1} \mathrm{~N}$ and between longitude $4^{0} 5^{1}$ and $5^{0} 46^{1}$. There are not less than 140 villages in Ekiti State with 16 Local Government Areas (LGAs). The state has a population of about 3,930212 people (NPC, 2006). Temperatures in the state range between $21^{\circ} \mathrm{C}$ and $28^{\circ} \mathrm{C}$ with high relative humidity. Topical forest exists in the South while Guinea Savannah occupies the Northern part (Figure 1).

\section{Sampling Techniques}

The data for this study were derived from household' survey that was conducted in 6 LGAs of Ekiti State. The first stage involves random selection of 6 LGAs out of the 16 LGAs in the State. The selected LGAs are: Ekiti South-West, Gbonyin, Irepodun/Ifelodun, Ekiti West, Ido-Osi and Oye. In the second stage two communities each were randomly selected from the selected 6 LGAs. Ten questionnaires were administered to randomly selected household in each of the selected communities to make up a sample size of 120 households. However, only 100 questionnaires were returned and analysed. The study covered 2010/2011 cropping seasons. 


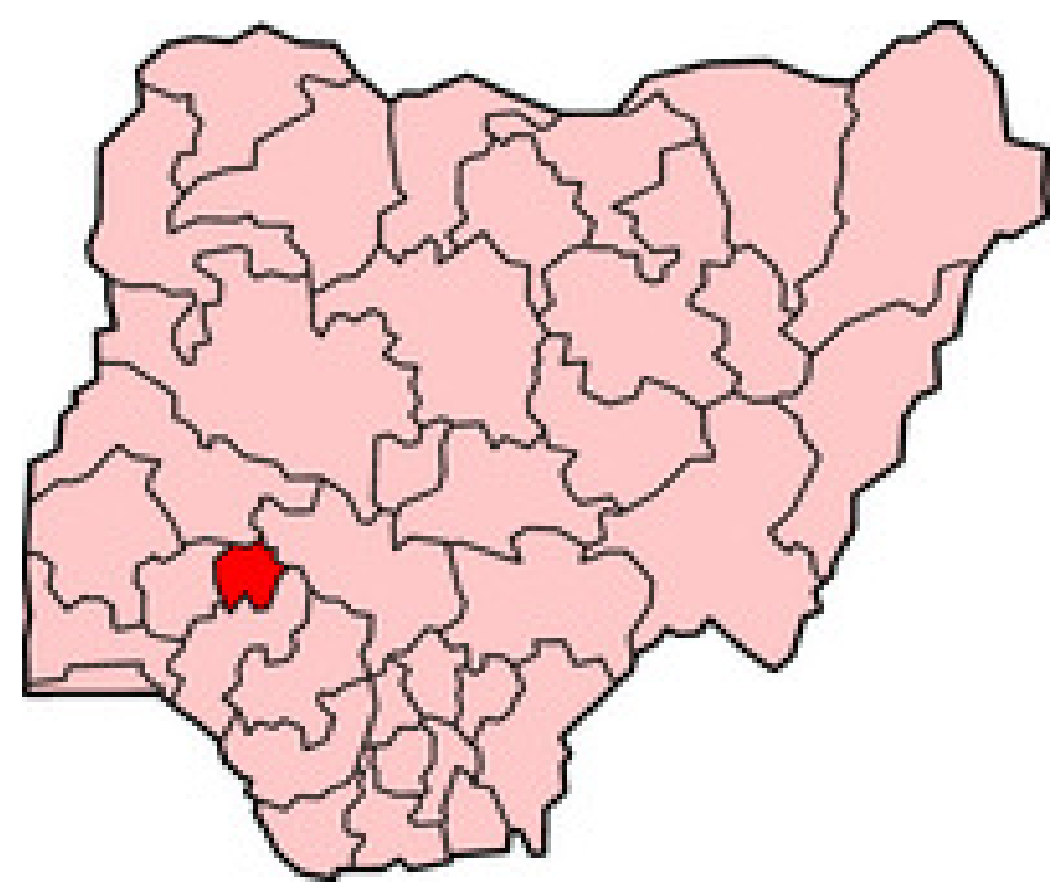

Figure 1 Map of Nigeria Showing Ekiti State

\section{Analytical Techniques}

Descriptive statistics like frequencies, average standard deviation and coefficient of variation were used throughout the whole studies.

\section{Results and Discussion}

Table 1 show that majority of the respondents were young with about $79 \%$ fallen within the age of 31 to 60 . The age of the farmer according to Adewumi and Omotesho, (2002) is expected to affects his labor productivity and output. It also affects the adoption of innovation in traditional farming. The mean age of the respondents is 49.4 years and the modal age is 31-60 years, which constituted about two-third of the total respondents. This might have implication for available family labor force. Given the ageing nature of the sample, there might be a reduction in the effective labor force for agricultural productivity in the study area.

It was observed during the field work that $79 \%$ and $21 \%$ of the sampled respondents in the study area were male and female respectively. This may be due to cultural belief of the people in the area, which prohibits women to go out freely and engage in certain activities such as farming. Where the women own a land, they usually delegate its administration to their senior male child or one of their male relations. The study revealed that more than ninety percent of the respondents were married, while the remaining were either single or widows/widowers, respectively. This, coupled with the polygamous nature of the area probably explained the large family size recorded in the area. The mean family size was 9 persons per respondent and it range from 1 to 19 . About $40 \%$ of the respondents have family sizes greater than this average number. This study also revealed that almost all the respondents have one form of education or the other, $39 \%, 31 \%$ and $10 \%$ have primary, secondary and adult education respectively. Given this level of literacy it is expected that information can be disseminated with ease among these households' heads. Basically, the levels of education of households' heads have significant impact on productivities, income earning opportunities and ability of farming households heads to effectively adopt better management practices.

Almost all the respondents have inherited farming as an occupation, while the remaining were introduced to farming by either friends or relatives. About Ninety percent of the respondents have farming as their main occupation and only ten percent adopts farming as their secondary 
occupation. The farmers $(60 \%)$ who engaged in farming on full time basis are expected to be more efficient and prepared to explore new methods that offer increases in farm income, compared to those who engaged in farming part time basis. Farmers experience is expected to have a considerable effect on farmer's productive efficiency. The farmer's years of experience range from 8 to 40 . The average farming experience of the farmers is 19.25 years. About $50 \%$ of the respondents have more than 15 years of experience in farming. The average farm size was 3.24 hectares among the farming household heads in the study area.

\section{Households' Head Perception on the Impact of} Climate Change

Table 2 shows that $90 \%$ of the respondents are aware of climate changes while the remaining $10 \%$ are ignorant about the changes. The most noticeable climate changes among the respondent is low rainfall $(55 \%)$. This is followed by high rainfall about $16 \%, 17 \%$ of the respondents noticed unfavourable sunlight. Rainfall is the most important factor in crop production about $89.0 \%$ of the respondents claimed that rainfall is very important for crop growth and development; this is followed by temperature (11.0\%). About $79 \%$ of the respondents experienced some climatic failures while the remaining $21 \%$ recorded that none of the climatic factors ever failed them throughout last season. The distribution of the respondents by the effect of climate changes on production reveals that $60 \%, 6 \%$ and $5 \%$ of the respondents claimed reduced yield, food insecurity and no effect respectively. It was also observed that on the average the farmers' output before climate changes was more than what it was after climate changes.

The independent samples t-test shows that $\mathrm{t}$ values are significant at $1 \%$ level for cassava-yammaize; cassava-sorghum-maize, and cassava-maize enterprises. According to Madu and Aogu, (2009), rainfall variability resulting from climate change results in decreased yield of some crops in Nigeria. The reductions in crop yields may lead to falling agricultural production and higher prices for food, which could trigger regional food crises. This would lead to greater food insecurity, causing political instability, increasing the stakes for control over productive agricultural land and further undermining the economic performance of the vulnerable states (Madu, 2006). Consequently, the pattern of vulnerability to climate change in
Nigeria is very worrisome because the more vulnerable states coincidentally the major food producing states.

\section{Coping strategies due to variation in climatic condition}

Coping strategy is an adjustment or self insurance pursued by farmers to ensure future income generation from crop production and minimize the adverse effects of climate change on productivity. From Table 3, majority (44\%) of the respondents switch to other source of income when there is unpredictable variation in climate condition, 23\% adopt delay-planting techniques, $16 \%$ changes varieties of cocoa used while the remaining $17 \%$ adopt some other strategies.

\section{Conclusion and Recommendations}

The study examined the vulnerability of crop farming households in Ekiti State to climate change. A total of 120 respondents were randomly selected however, only 100 questionnaires were returned and analysed. Result indicated that the farming households Ekiti States were young, mainly males, literates, experienced but relied mainly on personal savings and money borrowed from friends and relatives for farming. The land management methods mostly practiced is mulching and this is closely followed by fertilizer application and water harvesting. Climate change resulted in low productivity, low income, poor health as well as poor standard of living of the respondents. Based on the aforementioned findings, there is urgent need for policy intervention to safeguard the situation. The following recommendations were made: 1) Government should encourage farming households in Ekiti State to obtain loan from banks and micro-credit institutions. This can be done by reducing interest rate on loans for crop production as well as removing the stringent conditions attached to loans. 2) The adaptation responses to the risks posed by climate change on agriculture should be incorporated as part of sectoral policies in agriculture and poverty alleviation strategies. 3) It also involves the encouragement of land use change in places where the threat of climate change makes the continuation of an economic activity impossible or extremely risky. For instance crop land may be returned to pasture or forest or other uses may be found such as recreation, wildlife refuges, or national parks. 


\section{References}

Alao, O.S., 1999. The Effects of Agro-Climatic Factors on Food Crops Production in Nigeria. B.Sc. Thesis, Department of Agricultural Economics, University of Ibadan, Ibadan.

Erda, L I, Yinlong X; Shaohong W; Hui S. I; and Shiming M \{2007\}: China's National Assessment Report on climate Change $\{I I\}$ : Climate Change Impacts and adaption Advances in Climate Research, SPPC 0006-06 1673-1719http/unffccc. int/ files / adaptation / adverse effects and response measures art 48/application/POF/200609 background African wkshp. pdf http://www.ifpri.org/pubs/dp/ifpridp00806.pdfasse $\underline{\text { ssed07/09/2009 }}$

IPCC \{2001\}, "Climate change 2001: Impacts, Adaption and Vulnerability Working Group Contribution to the Third Assessment Report of the Intergovernmental Panel on Climate Change; "chapter 18: Adaptation to Climate Changing the contest of Sustainable Development and Equity" Cambridge University Press, Cambridge, PP. *877-912.

IPCC \{2007\} Climate Change: Impacts, Adaption and Vulnerability Working Group II Contribution to the Intergovernmental Panel on Climate Change: Summary for policy makers: IPCC Secretariat: Geneva Switzerland.

Jagtap, S.S., 1995. Discovery and innovation changes in annual, seasonal and monthly rainfall in Nigeria and consequences to agriculture. J. Afr. Acad. Sci., 7: 311-426.

Klein, R. J. T \{2004: Approaches, methods and tools for climate change impact, Vulnerability and Adaption Assessment Keynote lecture to the insession Workshop on impacts of and Vulnerability and Adaption to, climate change. Twenty-first session of the UNFCCC Subsidiary Body for Scientific and Technical Advice, Business Aires, Argentina, 8 December 2004.

Madu. I.A. and Ayogu, C.N. (2009): The Effects of Rainfall Variability on Crop Productivity in Northern Nigeria. Being a paper presented at National Conference on Climate Change and the Nigerian Environment Held at Princess

Alexandra Auditorium, University of Nigeria, Nsukka from29th June-29th June 2nd July 2009

Madu, I.A. (2006): Spatial Inequality in Nigeria: The Imperative of Geographic Perspectives in the Development Process. Journal of Social and Economic Development (JSED) Vol. 8 No. 2 pp. $105-120$

Nest \{2004\}, Regional Climate Modeling and Climate Scenarios Development in Support of Vulnerability and Adaptation Studies: Outcome of Regional Climate Modeling Efforts over Nigeria, Nigerian. Environmental Study/Action Team $\{$ NEST $\}$, Ibadan, Nigeria.

Okunmadewa, F., 2003. Risk vulnerability in agriculture: Concept and context. Development of Agricultural Economics. Pender J.J 2008. What is climate change? And how it will affect Bangladesh. Briefing Paper \{final draft\} Dhaka Bangladesh Church of Bangladesh Social Development Programme.

Preston, B. L, TM Smith, C. Brooke et al $\{2007\}$, mapping climate change Vulnerability in the $S C C G$ region. A report for the SCCG and the Australia Green house office. CSIRO Marine and Atmospheric Research, Aspen data, VIC, Australia.

Santiago, O., 2001. Vulnerability and adaptation to climate changes concepts and issues, assessmentmethods.http://www.cckn.net/pdf/va_fo undation_final.pdf.

Sygna .L. $\{2005\}$ Climate Vulnerability in Cuba: The role of social networks CICERO Working Paper 2005: 01

UNFCC \{2007\}: Climate Change: Impacts, Vulnerability and Adaptation in Developing countries. Bonn, UNFCC secretariat Watson, R T, MC-Zinvowera R. H. moss and D.J. Dokken \{1997\}: The Regional Impacts of Climate change: An assessment of Vulnerability a special Report of IPCC working group II, published for the IPCC.

WBGU \{German Advisory Council on Global Change $\{2008\}$, world in Transition Climate Change as a Security Risk, German Advisory council on Global change, Eartsh Scan, London.

United National Conference on trade and Development $\{$ UNCTD $\}\{2009\}$ Developing country Interests in Climate Change action and the applicators for a Post-2012 climate change region United Nation New York and Geneva, 2009. 
Table 1 Socio-demographic characteristics of household Head

\begin{tabular}{|c|c|c|}
\hline Characteristics & Frequency & Percentage \\
\hline \multicolumn{3}{|l|}{ Sex } \\
\hline Male & 79 & 79.0 \\
\hline Female & 21 & 21.0 \\
\hline Total & 100 & 100.0 \\
\hline \multicolumn{3}{|l|}{ Age } \\
\hline $01-30$ & 04 & 04.0 \\
\hline $31-60$ & 79 & 79.0 \\
\hline $61-90$ & 17 & 17.0 \\
\hline Total & 100 & 100.0 \\
\hline \multicolumn{3}{|l|}{ Household size } \\
\hline $01-5$ & 42 & 42.0 \\
\hline $06-10$ & 20 & 20.0 \\
\hline $11-15$ & 21 & 21.0 \\
\hline $16-20$ & 17 & 17.0 \\
\hline Total & 100 & 100.0 \\
\hline \multicolumn{3}{|c|}{ Nature of farm business } \\
\hline Full time & 60 & 60.0 \\
\hline Part time & 40 & 40.0 \\
\hline Total & 100 & 100.0 \\
\hline \multicolumn{3}{|l|}{ Farm size (ha) } \\
\hline $0.1-1.50$ & 15 & 15.0 \\
\hline $1.51-3.00$ & 30 & 30.0 \\
\hline $3.01-4.50$ & 30 & 30.0 \\
\hline $4.51-6.00$ & 25 & 25.0 \\
\hline Total & 100 & 100.0 \\
\hline \multicolumn{3}{|l|}{ Farming Experience } \\
\hline $01-15$ & 50 & 50.0 \\
\hline $16-30$ & 25 & 25.0 \\
\hline $31-45$ & 25 & 25.0 \\
\hline Total & 100 & 100.0 \\
\hline \multicolumn{3}{|c|}{ Education Status of the Household Head } \\
\hline & 02 & 02.0 \\
\hline No formal Education & 10 & 10.0 \\
\hline Quranic Education & 39 & 39.0 \\
\hline \multirow{2}{*}{ Primary Education } & 31 & 31.0 \\
\hline & 08 & 08.0 \\
\hline Secondary Education & 10 & 10.0 \\
\hline \multicolumn{3}{|l|}{ Tertiary Education } \\
\hline \multicolumn{3}{|l|}{ Adult Education } \\
\hline Total & & \\
\hline
\end{tabular}


Table 2 Households' Head Perception on the Impact of Climate Change

\begin{tabular}{|c|c|c|}
\hline Variables & Frequency & Percentage \\
\hline \multicolumn{3}{|l|}{ Distribution of respondents by Awareness } \\
\hline Yes & 90 & 90.0 \\
\hline No & 10 & 10.0 \\
\hline Total & 100 & 100.0 \\
\hline \multicolumn{3}{|c|}{ Distribution of respondents by most noticed climate changes } \\
\hline High Rainfall & 16 & 16.0 \\
\hline Low Rainfall & 55 & 55.0 \\
\hline High Temperature & 06 & 06.0 \\
\hline Unfavourable Sunshine & 17 & 17.0 \\
\hline Others & 06 & 06.0 \\
\hline Total & 100 & 100.0 \\
\hline \multicolumn{3}{|c|}{ Distribution of respondents by climate factors failure } \\
\hline Yes & 79 & 79.0 \\
\hline No & 21 & 21.0 \\
\hline Total & 100 & 100.0 \\
\hline \multicolumn{3}{|l|}{ Distribution of respondents by failing factors } \\
\hline Rainfall & 77 & 77.0 \\
\hline Sunshine & 12 & 12.0 \\
\hline Both & 11 & 11.0 \\
\hline Total & 100 & 100.0 \\
\hline \multicolumn{3}{|c|}{ Distribution by respondents by effects of climate failures } \\
\hline Reduced weight & 74 & 74.0 \\
\hline Disease & 08 & 08.0 \\
\hline Pest & 13 & 13.0 \\
\hline Others & 05 & 05.0 \\
\hline Total & 100 & 100.0 \\
\hline \multicolumn{3}{|c|}{$\begin{array}{l}\text { Distribution by respondents by degree of importance of climate variables in } \\
\text { production }\end{array}$} \\
\hline Rainfall & 89 & 89.0 \\
\hline Temperature & 11 & 11.0 \\
\hline Others & 100 & 100.0 \\
\hline \multicolumn{3}{|c|}{ Distribution of respondents by the effect of climate changes on production } \\
\hline Decrease in crop yield & 60 & 60.0 \\
\hline Decline in livestock production & 8 & 08.0 \\
\hline Increase in crop yield & 4 & 04.0 \\
\hline Increase in livestock production & 1 & 01.0 \\
\hline Death of livestock & 5 & 05.0 \\
\hline Food shortage/insecurity & 6 & 06.0 \\
\hline Food price increase & 11 & 11.0 \\
\hline No effect & 5 & 05.0 \\
\hline Total & 100 & 100.0 \\
\hline \multicolumn{3}{|l|}{ Output level before climate change } \\
\hline$>10 \mathrm{mt} / \mathrm{ha}$ & 26 & 26 \\
\hline $10-19 \mathrm{mt} / \mathrm{ha}$ & 38 & 38 \\
\hline $20-30 \mathrm{mt} / \mathrm{ha}$ & 32 & 32 \\
\hline$\leq 40 \mathrm{mt} / \mathrm{ha}$ & 4 & 4 \\
\hline $\bar{T}$ Total & 100 & 100 \\
\hline \multicolumn{3}{|l|}{ Output level after climate change } \\
\hline$>10 \mathrm{mt} / \mathrm{ha}$ & 47 & 47 \\
\hline $10-19 \mathrm{mt} / \mathrm{ha}$ & 23 & 23 \\
\hline $20-30 \mathrm{mt} / \mathrm{ha}$ & 30 & 30 \\
\hline$\leq 40 \mathrm{mt} / \mathrm{ha}$ & - & - \\
\hline Total & 100 & 100 \\
\hline
\end{tabular}


Table 3 Distribution of Household Heads Based on Coping Strategies

\begin{tabular}{lcc}
\hline Strategies & Frequency & Percentage \\
\hline Use of Land management practices & 67 & 67.0 \\
Yes & 33 & 33.0 \\
No & 100 & 100.0 \\
Total & & \\
Coping strategies mostly adopted & 44 & 44.0 \\
Other sources of income & 06 & 06.0 \\
Water harvesting & 11 & 11.0 \\
Crop diversification & 23 & 23.0 \\
Delayed planting techniques & 16 & 16.0 \\
Changes varieties & 100 & 100.0 \\
Total & & 34.0 \\
Type of climate change mostly addressed & 34 & 14.0 \\
Rainfall change & 14 & 41.0 \\
Temperature change & 41 & 11.0 \\
Drought & 11 & 100.0 \\
Flooding & 100 & \\
\hline
\end{tabular}

